\title{
62. On a Type of Glacial Topography in the Northern Foot-hills of Tateshinayama, Shinano Province.
}

By Takuji OGawa, M.I.A.

(Comm. May 12, 1933.)

In the summer of 1932 the writer continued the study of glacial deposits in mountanous districts of Shinano Province, Central Japan. Among the results obtained by the field work, the find of fossil plant beds in association with the glacial drift is a fact worthy of note, promising to throw light on questions concerning climatic change in the Pleistocene period. The occurrence of the boulder-clay in terrace-like accidents of foot-hills fringing volcanic elevations, like those on the west of the Shinano-Echigo railway between Nagano and Takata, is also of significance as an indication of stages in development of the glacier. Where the drift devoid of stratification overlies unconformably older distinctly bedded deposits, the latter often bear manifest marks of disturbances caused by the pressure of moving ice masses on the substratum. These seem however to be interesting only in a collateral sense when compared with the occurrence of a peculiar topography in the tracts abandoned by a glacier of the Piedmont type in the foothills extended from the northern slope of Tateshinayama on the left bank of the Chikumagawa.

Tateshinayama with an altitude of $2530 \mathrm{~m}$ above sea-level is a prominent peak on the northern extremity of the volcanic ridge stretched from Yatzugatake, alluded in a previous paper. ${ }^{1}$ It is a lava cone formed of amphibole-pyroxexe-andesite, and its gradient to the north is steep in the upper third of the distance of $15 \mathrm{~km}$ between the summit and the old highway of Nakasendo, toward which the lower two-thirds is gently inclined, the ground on the route nowhere rising above $800 \mathrm{~m}$, except near Nagakubo on the west. Beyond the line an undulating surface in the form of an irregular quadrangle with the average altitude of $750 \mathrm{~m}$ occupies an area of about $70 \mathrm{sq} . \mathrm{km}$. bounded by the Chikumagawa on the east and north sides and by the Yodagawa on the west. The area is further divided by the Kagumagawa into

1) Proc. Vol. pp. 17-18. For a fuller detail on the occurrence of erratic blocks in the drift on the southwestern susono of the volcano, see "Chikyu," Vol, XVII (1932), pp. 1-8, et 159-170. 
two parts, of which the smaller eastern half has a monotonous surface locally known by the name of Mimakigahara, while the larger western being drained by tributaries of the river presents similar aspect only in the northern portion called Yayebara.

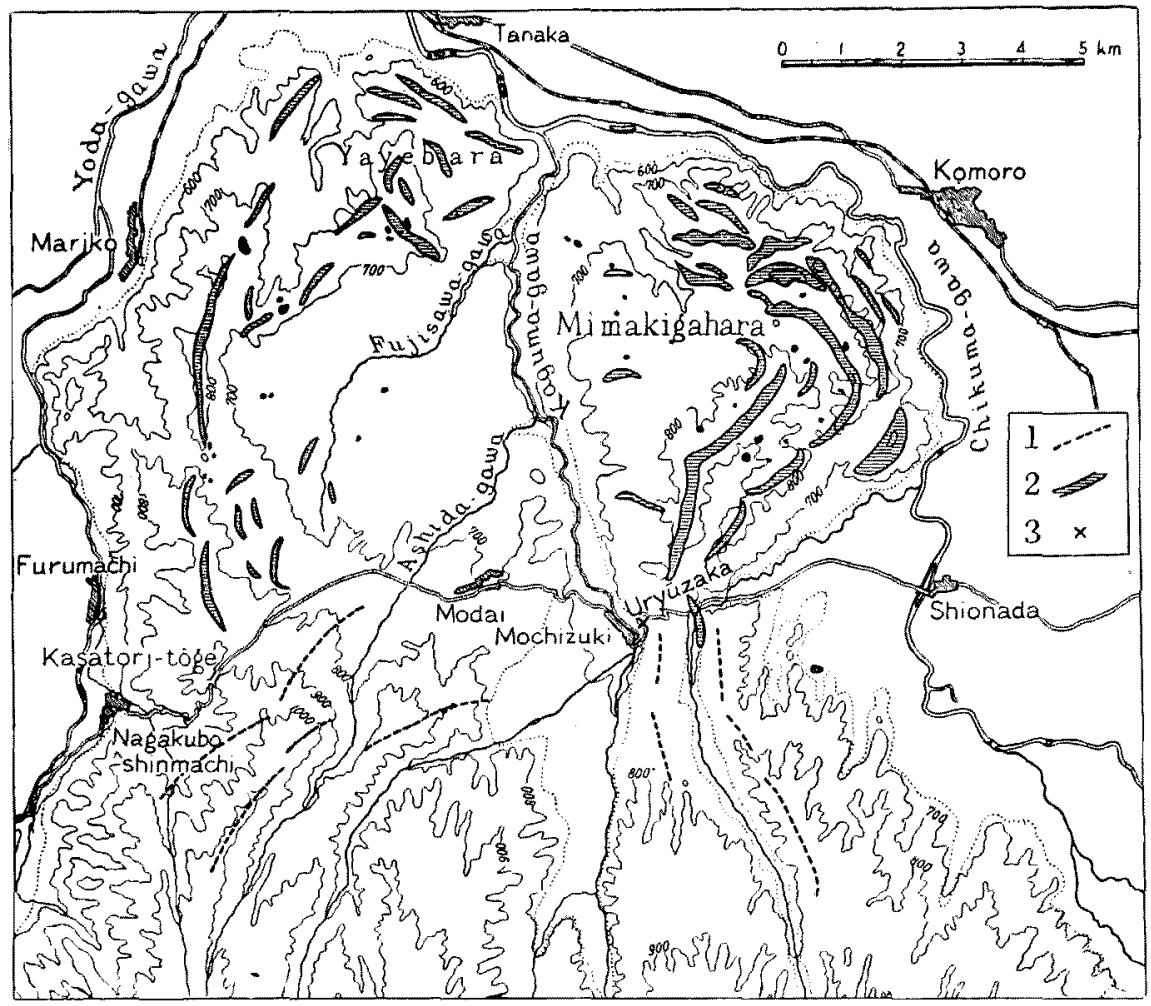

Fig. 1. Sketch map showing the moraine belts (2) on the plateau, Yayebara and Mimakigahara, beside the outcrop of an older boulder-clay (3) and the upper belts of a younger moraine (1).

A glance on the topographical map of the region (Sheets Komoro and Tateshina), suffices us to perceive a striking contrast in the mode of drainage of the quadrangle with that of the land south of the route, where the spurs on the northern slope of the volcano and their intervening valleys run parallel to one another. On tracing the contour lines of $600 \mathrm{~m}$ and $700 \mathrm{~m}$ in the interior, we find another fact of significance that the central portion has a lower altitude than the border with hilly belts forming more or less concentric arcs, especially on the east and west, raised some $200 \mathrm{~m}$ above the level of haras near the centre. The topographical feature should be a puzzle if we assume a normal degradation of running water alone to be responsible for the formation of the basin-shaped depression, for the hydrographic nets are not at all close enough to produce such an effect on the surface.

The quadragle of a flat surface raised $200-300 \mathrm{~m}$ above the level 
No. 5.] On a Type of Glacial Topography in the Northern Foot-hills.

of the bed of the Chikumagawa and its tributaries is a plateau of Pleistocene deposits. According to MM. F. Homma and S. Koyama," the clay, sand and gravel of the Shiogawa series occupy the base and are of the older Pleistocene age. The strata are successively overlain by the older terrace gravel and the loam, which represent the younger stages of the same age and are surrounded by the younger terraces of the Alluvium. The last-named gentleman kindly accompanied the writer in his reconnoitre of the route of Nakasendo from Shionada on the Chikumagawa to Nagakubo and directed his attention to the inquiry on the stratigraphical relation of the strata exposed on the road descending the low pass of Uryūzaka to Mochizuki on the Kagumagawa. In a second visit to the place in last August, it was found that the lowest member cropping out close by the opposite bank of the village is an agglomerate of pyroxene-andesite which is made of small scoraceous fragments cemented in a matrix of a volcanic ash coloured reddish brown, and unconformably overlain by a light greyish stiff boulder-clay containing pebbles of siliceous Palæozoic slate, quartzite and porphyrite beside abundant larger subangular blocks of pyroxeneandesite. The unstratified bed is estimated to amount to about $20 \mathrm{~m}$ in thickness. Next come the outcrops of a light yellowish grey laminated sandy clay of the Shiogawa series in its proper sense, $30-40 \mathrm{~m}$ thick, insensibly inclined eastward. Its lower horizon has a banding of dark grey layers. It is followed upward by a gravelly sand with false bedding. Its boundary to the underlying clayey member is not clear here as desired.

From the top of Uryüzaka, situated about $750 \mathrm{~m}$ above sea-level, a path ascends northwards a gentle acclivity to Mimakigahara to altitudes above $800 \mathrm{~m}$. A bed of yellowish sandy clay containing rounded blocks of andesite appears here over the gravelly sand exposed on the saddle and goes over to the brown-cloured clayey soil, designated by MM. Homma and Koyama as the loam (IV) in their geological map of the district. As admitted by the gentlemen, isolated blocks of andesite, sometimes of large size, are scattered on the surface of the hara covered with the brown soil. The mode of formation and stratigraphical relation of the uppermost member are not to be ascertained here on the height with the same facility as in excellent outcrops of the river banks on the feet of the plateau, next to be discussed.

1) Geology of the Central Districts of Shinano with hypsometrical and geological Maps, $1: 120,000$, Tokyo, 1931, p. 83, pp. 190-195. 
Nevertheless the observations induce us to form a tentative inference that the member may be of the same origin as that underlying the laminated clay, both representing the boulder-clay transported by glaciers formerly existed on mountains, mostly of volcanic origin and presumably on the south and southwest of the region.

The Chikumagawa, on its northward course along the eastern border of the plateau, excavates cliffs at many places, one of which at Aibama is by far most interesting. It is situated on the left bank, $2 \mathrm{~km}$ south of the route crossing the stream between Shionada and Mikurumayose. The Pleistocene strata form here a vertical wall about $30 \mathrm{~m}$ high and more than $500 \mathrm{~m}$ long above the water flowing in torrents. The laminated clay of dark grey colour with intercalations of white layers partly similar to that on Uryūzaka forms the whole wall on the northern part, while the strata are covered by a typical white boulder-clay cementing andesite blocks of variable size beside huge blocks of the gravel layer which separates the clay from the underlying laminated clay. Unconformity is clearly discerned along the boundary between the dark-coloured substratum and the white unstratified clay resting on it. On a close examination the lower member is found to have an intra-stratal overthrust fault directed northeastward. The southwestward inclination of detatched pieces of the gravel bed points the movement of the supercumbent drift in the same direction. A thin layer of the pale-cloloured bands in the upper part of the clay is also found to have been bent up and overturned in the same course. These evidences show us that the same boulder-clay as that forming Mimakigahara appears on the margin of the plateau and the deposit together with the strata of Shiogawa Series have been subjected to an enormous pressure of the ice mass in the interior of the glacial tongue.

From what stated above the writer believes to be entitled to conclude that the hilly tracts with a central depression is an area formerly covered by an ice lobe of the Piedmont type, though small compared with those of the northern foreland of the Alps or of the Alaskan coast. It may be added here that the rare instance of preservation of the original glacial topography in the region is due to a comparative dryness of local climatic condition, as should be expected from the configuration of surrounding mountains. 